IFN Working Paper No. 1018, 2014

\title{
Taxation of Real Estate in Sweden (1862-2013)
}

\author{
Mikael Stenkula
}




\title{
Taxation of Real Estate in Sweden (1862-2013) ${ }^{*}$
}

\author{
Mikael Stenkula
}

September, 2015

\begin{abstract}
This paper examines the development and role of the real estate taxation in Sweden during the period between 1862 and 2010. Real estate has historically been taxed at both the local and state levels. The importance of real estate taxation in Sweden is nevertheless difficult to assess directly because of the limited availability of data and the specific construction of the local tax system after 1920. The real estate tax initially aimed to provide municipalities with a stable tax base; however, its importance in this respect has diminished over time. After the tax reform of 1990-1991 in Sweden, real estate was taxed exclusively at the national level, generating tax revenue of approximately one percent of GDP. Further, in 2008, part of the tax was transformed to a "local fee".
\end{abstract}

JEL-codes: H20, N43, N44

Keywords: Real estate tax, property tax, tax reforms

\footnotetext{
* This is the working paper version of a chapter with the same title published in Swedish Taxation: Developments since 1862 (ch. 7, pp. 303-327), edited by Magnus Henrekson and Mikael Stenkula, New York: Palgrave Macmillan. The author gratefully acknowledges financial support from the Jan Wallander and Tom Hedelius Research Foundation as well as from the Marianne and Marcus Wallenberg Foundation. I am grateful for comments from Stig von Bahr, Dan Johansson, Magnus Henrekson, Hans Lind and Stellan Lundström.
} 


\section{Introduction}

Taxation of land, property and real estate has historically been an important income base for governments. Today, real estate taxation is often considered a stable and less distortionary tax source. ${ }^{1}$ Although the extent of real estate taxation varies widely across countries, real estate is taxed nearly everywhere in the developed world. Real estate taxation is nevertheless more controversial than many other types of taxation. ${ }^{2}$

The purpose of this paper is to briefly describe the evolution of real estate taxation in Sweden between 1862 and 2013. ${ }^{3}$ The study is part of a comprehensive effort to characterize the Swedish tax system over this long period. This paper focuses exclusively on taxation directly related to real estate. ${ }^{4}$ Analyzing the nature and important role of real estate taxation is more difficult than analyzing those of many other types of taxation. Indeed, the real estate tax in Sweden was generally an integral part of the ordinary income tax system; thus, specific statistics on real estate taxation are not available. Further, the construction of real estate taxation at the local level also makes an analysis of real estate taxation in Sweden less straightforward.

This paper is organized as follows. In the next section, some general principles behind real estate taxation are presented. The third section describes the evolution of real estate taxation between 1862 and 2013. Against this background, the fourth section evaluates the importance of real estate taxation in Sweden, and the fifth section discusses other taxes on real estate. Finally, the sixth section presents a brief summary and our main conclusions.

\section{General principles behind real estate taxation}

A government can tax real estate in many different ways. It can tax property with a distinct separate tax, where the taxpayer pays a part of the value of real estate directly via tax (objektskatt). It can also integrate real estate taxation with the ordinary income tax and tax the yield or return on real estate (avkastningsskatt). In this case, the tax can be based on the true

\footnotetext{
${ }^{1}$ The expressions “property tax" or "property taxation” are also used. Property tax also occasionally refers to wealth tax in general. In this paper, we use the term "real estate taxation."

${ }^{2}$ The basis for real estate taxation in Sweden has been discussed and examined, for example, in many Swedish Official Reports (Statens offentliga utredningar), including SOU 1942:34, 1953:8, 1960:4, 1973:4, 1974:16, 1976:11, 1979:32, 1986:4-6, 1992:8, 1992:11, 1993:57, 1994:57, 1999:59, 2000:10, 2000:34, 2012:52.

${ }^{3}$ The study period begins in 1862 because a major and pivotal (income) tax reform was implemented in that year.

${ }^{4}$ A taxpayer may also have to pay wealth tax based on the assessed value of real estate and capital gains tax when a property is sold. Related taxes, such as the stamp duty or excise duty on forestry, are discussed in section 4.1. For a comprehensive historical review of the complex evolution of Swedish wealth taxes, see Du Rietz and Henrekson (2015).
} 
income associated with real estate. Such a system, in which the true income associated with real estate is taxed (allowing for deduction of costs), is called a conventional system. ${ }^{5}$ Many housing types, such as owner-occupied housing, do not normally generate any true taxable income; thus, a strictly conventional method may generate little or no tax revenue. Assessing deductible costs may also be difficult for tax authorities. Instead of using the true income, the imputed income of real estate, for example, based on the assessed value of property, can be used. This approach has been extensively used in Sweden.

Taxation of real estate is often criticized on a number of grounds. Such a tax is considered unfair or unjust because it does not necessarily fall upon taxpayers with high income or substantial (financial) wealth. Further, the tax is levied not on a direct taxable income flow but on a non-pecuniary return. Therefore, a taxpayer may not have the available cash to pay the tax. In addition, as the tax is often based on the assessed value of real estate and as this assessed value can increase sharply, the taxpayer's tax burden may suddenly increase without any corresponding increase in income or financial wealth. It may seem odd if the taxpayer must borrow money (with the increased value of the real estate as collateral) to pay the tax. One general principle within the literature on taxation is that taxes should be levied upon taxpayers in proportion to their ability to pay; real estate tax seems prima facie to violate this principle.

Numerous arguments nevertheless support some sort of real estate taxation. In Sweden, three arguments have dominated. ${ }^{6}$ First, real estate taxation is argued to provide municipalities with a stable tax base. Many investments by local authorities, such as infrastructure investment, also benefit real estate owners and may increase the value of their property. Hence, real estate tax can be regarded as being levied in proportion to the benefits that taxpayers receive. Second, proponents of real estate taxation argue that the tax system should be neutral. The concept of neutrality can refer to different aspects, and the focus of tax neutrality has changed over time. One aspect of neutrality relates to the neutrality of tenants vis-à-vis people in owner-occupied houses. Another aspect relates to the neutrality between, for example, saving capital in a bank account and investing capital in one's own home. This line of argument suggests that the tax system should be neutral between types of building or tenure and between different types of investments. Hence, if real estate is not taxed at all, the tax system will not be neutral.

\footnotetext{
${ }^{5}$ If a strict conventional system is used and if, for example, a company that owns apartments is taxed according to its true income and costs in the same way as other companies, it is doubtful whether a specific and distinct real estate tax can be legitimately discussed.

${ }^{6}$ SOU 2000:34, 73f.
} 
Finally, and related to the neutrality argument, real estate is said to generate a flow of “capital return” that should be taxed. In this case, the return on capital should refer to the value of housing (and increases in property value). However, this “return”, in contrast to returns on most financial assets, is non-pecuniary. As noted above, a conventional system cannot be used if this return on real estate is supposed to be taxed. One can propose various arguments about how to derive some form of taxable return from real estate, for example, by using some form of reasoning based on opportunity costs. Homeowners could let their house to a tenant if they are not living in the house themselves. A tax could be levied on the estimated imputed rent that the owners would receive. ${ }^{7}$ Homeowners could also sell their house and invest the money elsewhere. A tax could be levied on the estimated yield of this alternative investment. This yield provides a reasonable estimate of the "capital return” on the real estate.

Governments can choose whether to tax natural persons and/or legal entities. As usual, the incidence of the tax is not necessarily borne by the subjects who actually pay it. For instance, a tax on an apartment building may be shifted to tenants through higher rent. A tax on commercial buildings and industries will affect firms' profits, which may ultimately affect consumer prices and consumer choice.

Real estate taxation is typically, in some way or another, based on the assessed value of property. ${ }^{8}$ As of 2006 in Sweden, the assessed value of property is determined annually but for different types of property each year (e.g., apartment buildings, one- or two-dwelling buildings). The assessed value of the same type of property was previously updated every six years. Now, however, property value can be assessed more often and in a simplified way that considers only changes in the market price (förenklad fastighetstaxering). ${ }^{9}$ The assessed value of property should correspond to 75 percent of the market value of the property. The law on assessed real estate was first introduced in 1810, and initially, the assessed value was determined every three years; however, during the 1900s, the assessment period was changed to every five years. Occasionally, the time period between assessments has exceeded five years (SOU 1979:32). In 1985, the Swedish government decided that the assessed value of property should be determined every six years (SOU 2000:10).

\footnotetext{
${ }^{7}$ Alternatively, the rent that owners avoid paying because they own the house can be regarded as a benefit that should be taxed.

${ }^{8}$ However, other possibilities exist. According to the so-called California model, real estate tax can be based on the purchase price of property (or the market value when the property was purchased). Such a system will increase the predictability of real estate tax but will also reduce residents' willingness to move.

${ }^{9}$ In 1996, special rules stipulating that the assessed value of property should be updated yearly were also introduced. However, these rules did not have a substantial effect because a special decision prevented the assessed values of property from increasing during the end of the 1990s.
} 


\section{The overall evolution of real estate taxation in Sweden ${ }^{10}$}

In the nineteenth century, Sweden had a state income tax system based on so-called appropriations (bevillning). This system can be traced back centuries. Originally, bevillning was a temporary surtax that was granted by Parliament when the government had special needs, for instance, during wartime. Over time, the surtax became a permanent part of the Swedish tax system. The system was rather heterogeneous, with roots in the economic and social order of the agricultural society. In 1862, the appropriation tax system was reformed. The system was simplified, and the income tax classification was reduced from eight to two categories: appropriation on real estate (fastighetsbevillning) and appropriation on labor or capital income (inkomstbevillning). The tax rate was set at one percent. ${ }^{11}$ The overall objective of this reform was to tax the entire annual return on all real estate. Given the extreme difficulty of assessing the annual return on all real estate in the country, some form of general rule had to be used instead to determine an imputed income from real estate.

Initially, the rules stipulated that three percent of the assessed value of agricultural property and five percent of all other property should be treated as taxable income. Because the tax rate was one percent, these rules implied that taxpayers had to pay 0.03 percent or 0.05 percent of the assessed value of real estate in taxes. Agricultural property had a lower tax rate because it was also subject to another type of tax (basic tax, see below). When the basic tax was gradually abolished beginning in 1892, the imputed return on agricultural property was increased to six percent. A rate of six percent was used because the category of agricultural property was assumed to encompass inventory and equipment (inventarier) estimated at a value of one percent that also should be taxed.

During this time, so-called grundskatter (“basic tax”), which was mainly a fixed lumpsum state tax often paid in kind, also existed. This tax was based on land that was not tax exempt, and it was the oldest existing tax at the time, being first introduced in the Middle Ages and forming the bulk of state tax revenue, where peasants with taxable estates were hit hardest. This tax was regressive; it was fixed and had to be paid even during poor harvest years. Over centuries, it evolved considerably. After 1869, it was possible to pay the tax

\footnotetext{
${ }^{10}$ This description is based on Eberstein (1929, 1937), Gårestad (1987), Löwnertz (2003), Skatteverket (2013), SOU 1953:8, SOU 1960:4 and SOU 2000:34.

${ }^{11}$ Occasionally, additional appropriation taxes were levied if the ordinary appropriation taxes yielded insufficient tax revenues. The tax rate could then be raised to two percent of income; see Du Rietz, Johansson and Stenkula (2015). A small amount was also tax exempt.
} 
solely with money. In 1885, the government began to reduce this tax, and it was reduced by ten percent per year between 1893 and $1902 .^{12}$

In addition to the grundskatter (basic tax), the mantalspenning, a poll tax that was a lump-sum tax paid by every person, was also in effect. This tax was introduced in 1625 during a period of intense warfare, and it was not abolished until 1938, by which time its importance was negligible.

At the local level, taxable income and the local income tax were based on the state appropriation system. Consequently, part of the assessed value of real estate was also included in taxpayers' income taxable at the local level. ${ }^{13}$ The tax rate paid on taxable income differed among municipalities. $^{14}$

In addition to this combined income and real estate taxation, some urban municipalities employed a separate local tax on real estate to finance, e.g., street maintenance and cleaning and garbage collection, which were necessary in the emerging and growing cities. ${ }^{15}$ Although small, the tax rate varied over time and across municipalities. However, its importance declined, along with the number of municipalities that used it.

In 1903, the state tax system was reformed, and a new state income tax system was introduced, though the taxation of real estate did not change. ${ }^{16}$ However, shortly thereafter, in 1911, the state tax system was once again reformed. With this reform, only the true income from real estate was taxed in the same way as other income (the conventional method). ${ }^{17} \mathrm{At}$ the local level, five (six for agricultural property) percent of the assessed value of property was included in taxpayers' taxable income, as described above.

\footnotetext{
12 This tax was not formally called grundskatter until it was decided that it would be abolished. Formally, this basic tax included several different types of taxes, including the jordeboksräntan, mantalsräntan and kronotiondet. Historically, this tax has been paid in kind, in the form of forced labor, e.g., day work (dagsverke), or in cash. Part of the tax was not paid to the local or state government but rather was given directly to military authorities or soldiers. During the 1600s, the so-called indelningsverket (allotment system) was established as a way to arm and finance the Swedish Army with so-called allotted soldiers. This system required farmers to equip and remunerate infantry soldiers. They could also volunteer to equip and remunerate cavalry soldiers, including cavalry horses. These farmers (called rusthållare) did not have to pay (part of) the basic tax. The complex allotment system was finally abolished in 1904, shortly after the compulsory military service was introduced in 1901.

${ }^{13}$ In rural municipalities (landskommuner), the income tax system was somewhat more complicated than in urban municipalities (stadskommuner) until 1910. Taxes, mostly paid in kind, were also used to maintain the roads.

${ }^{14}$ See Du Rietz, Johansson, and Stenkula (2015) for a description of the evolution of the local tax rate.

${ }^{15}$ Statistics Sweden (1920b).

${ }^{16}$ However, the old appropriation system remained in place until 1928, but at a symbolic tax rate of 0.1 percent after 1911.

${ }^{17}$ Most taxpayers did not have an income flow associated with their owner-occupied house. In practice, the tax authority could decide a hypothetical rental income and could base the tax on this estimation (see the discussion below).
} 
In 1920, local real estate taxation was reformed, and a new so-called guaranteed tax system (garantiskattesystem) was introduced. The new tax rules required income tax to be paid on an imputed income, set at five (six for agricultural property) percent of the assessed value of the property (for both private and commercial property). These figures, called repartition rates (repartitionstal), were the same as before the reform. However, the true income from real estate was also taxable (as in a conventional system), although the taxpayer could deduct the imputed income of five (six for agricultural property) percent from this taxable income (the so-called percent deduction [procentavdraget]). Hence, in this new system, there was no true additional tax on real estate if the income was higher than five (six for agricultural property) percent. The property tax was binding (or effective) for real estate with low or no true income only. ${ }^{18}$ Accordingly, this tax system provided municipalities with more tax revenue only if taxpayers could not use the percent deduction (partly or completely). The so-called effective rate (i.e., the share of the real estate tax that actually resulted from the real estate tax and that would disappear if the tax were abolished) varied over time and across properties. $^{19}$

It was argued that a (much simpler) conventional system without any "guaranteed" level could not be introduced because many municipalities would garner insufficient tax revenue to cover their expenses and because the difference among municipalities would be unacceptably large. The tax system implied that municipalities always received tax revenue up to the "guaranteed" level (equal to the local tax rate times five/six percent of the assessed value of real estate in the municipality). Overall, this system increased the stability of the local tax base and ensured that taxpayers with income associated with their real estate above the imputed income did not escape from paying taxes on this income.

This complicated system became permanent with the tax reform of 1928, when the appropriation tax was finally abolished. However, the repartition rate on forest land was reduced to four percent because forestry also paid an excise duty on forestry. Technically, the sources of taxable income were extended from three (real estate, labor and capital) to six. Real estate was split into two new classes (“agricultural property” and “other property”), and labor,

\footnotetext{
${ }^{18}$ If a taxpayer's income associated with his property is ten percent (of the assessed value) and if the repartition rate is six percent, the taxpayer pays income tax on six percent (of the assessed value) in "real estate tax" and on four percent $(10-6)$ in "ordinary" income tax. If the guaranteed tax system were abolished, the taxpayer would pay "ordinary" income tax on ten percent directly. In effect, the taxes paid do not differ. The real estate tax in this example is considered to be non-effective for the taxpayer, i.e., the tax is not binding. Hence, a high income implies that the real estate tax is not binding (non-effective), although the tax is formally paid.

${ }^{19}$ Owner-occupied houses had a high effective rate, while commercial properties normally had a much lower effective rate. Similarly, the term "effective tax amount” was used to refer to the amount that directly resulted from the real estate tax and that would disappear if the real estate tax were abolished.
} 
business, capital and capital gains composed the other four classes. The division between the ordinary local tax and the real estate tax can be considered an extension of the earlier division between the appropriation on real estate (fastighetsbevillning) and the appropriation on labor or capital income (inkomstbevillning). In 1932, the repartition rate on "agricultural property” was reduced to five percent, that is, the same repartition rate applied for "other property".

Considerable debate during the 1950s centered on the construction of the real estate tax, including the radical option of abolishing it altogether. ${ }^{20}$ In 1953, the construction of the local guaranteed tax system was altered; however, the principles of the system remained unchanged. ${ }^{21}$ The repartition rate was also reduced to four percent (in 1954) and then further to 2.5 percent (in 1957). However, the increase in the assessed value of property during this period completely or partly offset such reductions. The repartition rate was once more reduced in 1965 and then again in 1981 to two and 1.5 percent, respectively (see Table 1). The system was abolished altogether for natural persons in 1987 for the dual reasons that the tax system encouraged tax avoidance and that such a system (to provide the municipalities with a reasonable and stable, guaranteed tax revenue based on the value of real estate) was no longer necessary.

Table 1. The local guaranteed tax system, 1920-1986 (\%).

\begin{tabular}{lr}
\hline Year & Repartition rate \\
\hline 1920 & 5.0 \\
1954 & 4.0 \\
1957 & 2.5 \\
1965 & 2.0 \\
1981 & 1.5 \\
\hline
\end{tabular}

Note: Until 1932, the repartition rate was six percent on agricultural property. Source: SOU 1986:6, SOU 1993:57.

For owner-occupied houses, the 1953 reform entailed other important changes that affected both state and local taxation. ${ }^{22}$ Prior to this reform, the true income from real estate was part of the tax system. Many taxpayers, of course, did not have an income flow associated with their owner-occupied house. At the local level, this tax on the true income from real estate was combined with a guaranteed tax system that ensured tax income for local

\footnotetext{
${ }^{20}$ For example, it was argued that the system was unfair, complicated, and based on a non-pecuniary hypothetical yield that was difficult to tax.

${ }^{21}$ The real estate income tax was integrated with the ordinary local income tax. The system was still based on an imputed income on the assessed value of property; however, instead of a guaranteed tax (garantiskatt), the system was formally characterized by a guaranteed taxable income (garantibelopp).

${ }^{22}$ Owner-occupied houses refer to one- or two-dwelling buildings.
} 
authorities, even when little or no income was associated with a property. With the reform, formal rules for an imputed income were introduced for these properties (villaschablon). ${ }^{23}$ Only interest payments associated with the property, not other costs, were deductible from this imputed income. ${ }^{24}$

For owner-occupied houses, the rate of imputed income was initially set at three percent of the assessed value of property. ${ }^{25}$ The rate of imputed income was reduced to 2.5 percent in 1957 and then to two percent in 1965 (see Table 2). After 1967, the imputed rate of income depended on the assessed value of property, and the system was thus inherently progressive. Initially, the imputed rate varied between two and eight percent. ${ }^{26}$ The imputed rates and brackets were subsequently changed several times, often in response to changes in the assessed value of property (see Table 3). This system was finally abolished as part of the 1990-1991 tax reform. ${ }^{27}$

Table 2. Imputed rent on owner-occupied houses (villaschablonen), 1954-1966 (\%).

\begin{tabular}{lccc}
\hline Assessed value & 1954 & 1957 & 1965 \\
\hline $\begin{array}{l}\text { Independent of } \\
\text { value }\end{array}$ & 3.0 & 2.5 & 2.0 \\
\hline
\end{tabular}

Source: SOU 1974:16.

\footnotetext{
${ }^{23}$ The tax authority often estimated a hypothetical rental income before this tax reform. No formal rules stipulating how to perform this estimation existed. Over time, local authorities developed different standards, which varied among regions. Disputes about the estimated income and deductible costs associated with a property were common, and consequently, the rules were formalized and harmonized.

${ }^{24}$ This principle was based on the idea that tenants and people in owner-occupied houses should be treated equally. The aim was also to reduce the disputes between taxpayers and the tax authorities.

${ }^{25}$ Three percent corresponded to the interest rate on deposits in savings banks at the time. Because the tax base was three percent times the entire assessed value of the dwelling, reduced by the interest paid, this tax was clearly supposed to tax the implicit return on an owner's own investment in real estate.

${ }^{26}$ However, many homeowners could base their tax on the lowest imputed rate. In 1970, only 40,000 of 1,300,000 owner-occupied houses (three percent) had an assessed value above 150,000, the threshold of the second bracket (SOU 1973:4). The corresponding figure for 1982 was two percent (SOU 1986:6).

${ }^{27}$ The rules were also changed for housing associations (bostadsrättsföreningar), whose income was initially estimated to be three percent of the assessed value, as with owner-occupied houses. While no progressive tax system was introduced in 1967, from 1979 to 1987, part of the assessed value of the co-operative apartment was taxed as capital income by the owner. This system was abolished in 2007. Even public housing companies (allmännyttiga bostadsföretag) were taxed in this way until 1994.
} 
Table 3. Imputed rent on owner-occupied houses (villaschablonen), 1967-1990.

\begin{tabular}{lclc}
\hline $\begin{array}{l}\text { Assessed value } \\
\text { (thousands) }\end{array}$ & $\begin{array}{c}1967 \\
\%\end{array}$ & $\begin{array}{l}\text { Assessed value } \\
\text { (thousands) }\end{array}$ & $\begin{array}{c}1970 \\
\%\end{array}$ \\
\hline-100 & 2.0 & -150 & 2.0 \\
$100-200$ & 4.0 & $150-225$ & 4.0 \\
$200-$ & 8.0 & $225-$ & 8.0 \\
\hline
\end{tabular}

\begin{tabular}{lclclc}
\hline $\begin{array}{l}\text { Assessed value } \\
\text { (thousands) }\end{array}$ & $\begin{array}{c}1975 \\
\%\end{array}$ & $\begin{array}{l}\text { Assessed value } \\
\text { (thousands) }\end{array}$ & $\begin{array}{c}1978 \\
\%\end{array}$ & $\begin{array}{l}\text { Assessed value } \\
\text { (thousands) }\end{array}$ & $\begin{array}{c}1981 \\
\%\end{array}$ \\
\hline-200 & 2.0 & -200 & 3.0 & -450 & 2.0 \\
$200-250$ & 4.0 & $200-250$ & 4.0 & $450-600$ & 4.0 \\
$250-300$ & 8.0 & $250-300$ & 8.0 & $600-750$ & 6.0 \\
$300-$ & 10.0 & $300-$ & 10.0 & $750-$ & 8.0
\end{tabular}

Note: The tax rates refer to the tax rates applicable within the tax bracket. If the assessed value is 200,000, the imputed rent was $2 \% \cdot 150,000+4 \% \cdot(200,000-150,000)$ in 1970 . Occasionally, there was a small deduction. Source: SOU 1974:16, Bratt and Fernström (1978, 1979, 1981), Ds 1998:3.

During the 1980s, the taxation of real estate underwent substantial change. A separate state tax on real estate in addition to the existing real estate tax was introduced. The origin of this tax was a state fee on old apartment buildings, which was introduced in $1983 .{ }^{28}$ The tax rate was supposed to be two percent of the assessed value when it was finally implemented; however, for the first two years, there were some initial reductions, and the tax rate was only one and then 1.5 percent. This fee was primarily introduced because of changes in the state subsidy system for new apartment buildings, which would (unjustly) benefit owners of old apartment buildings.

In 1985, this fee was transformed into a more general state tax on real estate, including owner-occupied houses. ${ }^{29}$ Originally, the tax rate was supposed to be 1.4 percent for real estate that was taxed with an imputed income (owner-occupied houses, housing associations, and public housing companies) and two percent for real estate that was conventionally taxed (the tax was deductible for conventionally taxed real estate). The tax rate on owner-occupied houses was reduced during the first two years, and in 1988, the tax rate on apartment buildings was raised to 2.5 percent. The base for the tax rate was initially the assessed value of property for apartment buildings; however, for owner-occupied houses, it was only onethird of the assessed value. The rules were subsequently changed several times. Before the

\footnotetext{
${ }^{28}$ Old apartment buildings roughly refer to apartment buildings built prior to 1975 .

${ }^{29}$ The tax was implemented for fiscal reasons; however, it was also justified as a way to render the tax system more equitable and neutral. Hence, in the mid-1980s, owner-occupied houses were taxed in three different ways with an imputed rent income (villaschablon), with a specific real estate tax (state level), and with a guaranteed tax (local level). In many cases, there was an additional wealth tax.
} 
1990-1991 tax reform, the tax rate was 1.4 percent for owner-occupied houses and 2.5 percent for apartment buildings, and the tax base was one-third of the assessed value for owner-occupied houses and 65 percent of the assessed value for apartment buildings (see Table 4). ${ }^{30}$

Table 4. The state real estate tax, 1985-1990.

\begin{tabular}{|c|c|c|c|c|c|c|}
\hline & \multicolumn{2}{|c|}{1985} & \multicolumn{2}{|c|}{1986} & \multicolumn{2}{|c|}{1987} \\
\hline & Tax base & Tax rate & Tax base & Tax rate & Tax base & Tax rate \\
\hline \multicolumn{7}{|l|}{ Owner-occupied house } \\
\hline Conventionally taxed & $1 / 3$ & 0.5 & $1 / 3$ & 1.0 & $1 / 3$ & 1.4 \\
\hline Imputed & $1 / 3$ & 0.7 & $1 / 3$ & 1.4 & $1 / 3$ & 2.0 \\
\hline \multicolumn{7}{|l|}{ Apartment building } \\
\hline Conventionally taxed & $100 \%$ & 1.4 & $100 \%$ & 1.4 & $100 \%$ & 1.4 \\
\hline \multirow[t]{3}{*}{ Imputed } & $100 \%$ & 2.0 & $100 \%$ & 2.0 & $100 \%$ & 2.5 \\
\hline & \multicolumn{2}{|c|}{1988} & \multicolumn{2}{|c|}{1989} & \multicolumn{2}{|c|}{1990} \\
\hline & Tax base & Tax rate & Tax base & Tax rate & Tax base & Tax rate \\
\hline \multicolumn{7}{|l|}{ Owner-occupied house } \\
\hline Conventionally taxed & $1 / 3$ & 1.4 & $1 / 3$ & 1.4 & $1 / 3$ & 1.4 \\
\hline Imputed & $1 / 3$ & 2.0 & $1 / 3$ & 2.0 & $1 / 3$ & 2.0 \\
\hline \multicolumn{7}{|l|}{ Apartment building } \\
\hline Conventionally taxed & $55 \%$ & 1.4 & $55 \%$ & 1.4 & $65 \%$ & 1.4 \\
\hline Imputed & $55 \%$ & 2.5 & $55 \%$ & 2.5 & $65 \%$ & 2.5 \\
\hline
\end{tabular}

Note: The tax base refers to the share of the assessed value of real estate. Source: Andersson, Bratt and Svensson (1985), Bratt and Tolstoy (1986, 1988a, 1988b), Bratt (1989), Öberg (2008).

The 1990-1991 tax reform abolished the system with imputed income on owner-occupied houses. Taxpayers with owner-occupied houses then paid only the specific state tax on real estate. $^{31}$ The tax rate was initially supposed to be 1.5 percent on owner-occupied housing and 2.5 percent on apartment buildings. ${ }^{32}$ There was, however, a temporary reduction to 1.2

\footnotetext{
${ }^{30}$ In 1990, the tax base was also increased at a local level in some municipalities.

${ }^{31}$ With the tax reform, the sources of income were reduced to three (capital, labor and business), and commercial real property (näringsfastighet) and private residential property (privatbostadsfastigheter) were differentiated.

${ }^{32}$ One reason for these changes was to simplify the tax system. The principle behind the real estate tax regarding neutrality was then focused more on neutrality between different forms of investments (e.g., investing capital in owner-occupied housing versus saving capital in a bank) than on neutrality between different forms of housing (owner-occupied versus rental housing). The tax rate of 1.5 percent on owner-occupied houses was justified on the grounds that a reasonable nominal return on the capital invested was seven percent. Capital income was taxed at 30 percent after the tax reform, implying a tax rate of 2.1 percent. Swedish politicians wanted the tax rate to be somewhat lower than this rate to stimulate investments and homeownership. Taxation on future capital
} 
percent for owner-occupied houses for the first two years. The tax base was the entire assessed value, independent of property type. After the reform, this tax changed several times, and in 1996, the tax was broadened to encompass other property categories (see Table 5). ${ }^{33}$ There were also many exceptions and forms of temporary relief, notably for new buildings. Later, rules limiting the effective tax rate were introduced. Such rules included distinct caps on the tax on real estate in relation to a taxpayer's assessed income (for natural persons) and grants of a smooth and stepwise increase in the real estate tax in case of a sharp increase in the assessed value of a property.

The state real estate tax on owner-occupied houses and apartment buildings was abolished in 2008. Instead, a "local fee” was introduced with a cap, to be adjusted annually and was indexed to the so-called income base amount (inkomstbasbelopp), which tracks the average nominal income (initially the cap was SEK 6,000/house or SEK 1,200/apartment, see Table 6). ${ }^{34}$ Whether this local fee should be called a "fee" is questionable; however, the government used the term "fee" instead of "tax" to underline that it was a new system that was qualitatively different from the earlier, unpopular system. Whether the fee should be called a "local" fee is also questionable because the tax rate is ultimately determined by the state independently of local governments. The state also reduced its subsidies to the local governments by the same amount as the "local fee” generated. In practice, these changes initially implied a tax decrease for taxpayers with highly valued real estate but no positive effect on tax revenue at the local level.

Table 7 provides a general overview of the most important changes in the Swedish tax system for real estate.

gains once a property is sold was also accounted for. The capital gains tax was estimated to correspond to a real estate tax of 0.38 percent. Hence, the tax rate was set at 1.5 percent. See, e.g., SOU 2000:34, 65f for further discussion.

The total tax rate for owner-occupied houses before the reform, including the imputed rent (villaschablon), is estimated to have been 1.42 percent, according to SOU 1992:11. Thus, the taxation of owner-occupied houses was approximately the same after the reform as before the reform.

${ }^{33}$ The reason for a decrease in the real estate tax has often been an increase in the assessed value of property. As in 2001, the decrease can simply be due to a stronger negative attitude toward real estate taxes among potential voters and taxpayers. The reason for the increase and broadening of the real estate tax in 1996 was almost purely fiscal. The change in tax policy was also argued to be a way to finance membership in the EU.

${ }^{34}$ SEK = Swedish kronor. There were roughly five Swedish kronor to the US\$ during the Bretton Woods era. In recent decades the exchange rate has, with few exceptions, oscillated between six and nine kronor to the dollar. 
Table 5. The state real estate tax, 1991-2013 (\%).

\begin{tabular}{|c|c|c|c|c|}
\hline Year & $\begin{array}{r}\text { Owner-occupied } \\
\text { houses }\end{array}$ & $\begin{array}{c}\text { Apartment } \\
\text { buildings }\end{array}$ & $\begin{array}{r}\text { Commercial } \\
\text { premises }\end{array}$ & $\begin{array}{r}\text { Industrial } \\
\text { property }\end{array}$ \\
\hline 1991 & 1.2 & 2.5 & $3.5^{*}$ & 0.0 \\
\hline 1992 & 1.2 & 2.5 & $3.5^{*}$ & 0.0 \\
\hline 1993 & 1.5 & 2.5 & 0.0 & 0.0 \\
\hline 1994 & 1.5 & 1.5 & 0.0 & 0.0 \\
\hline 1995 & 1.5 & 1.5 & 0.0 & 0.0 \\
\hline 1996 & 1.7 & 1.7 & 1.0 & 0.5 \\
\hline 1997 & 1.7 & 1.7 & 1.0 & 0.5 \\
\hline 1998 & 1.5 & 1.5 & 1.0 & 0.5 \\
\hline 1999 & 1.5 & 1.3 & 1.0 & 0.5 \\
\hline 2000 & 1.5 & 1.2 & 1.0 & 0.5 \\
\hline 2001 & 1.0 & 0.5 & 1.0 & 0.5 \\
\hline 2002 & 1.0 & 0.5 & 1.0 & 0.5 \\
\hline 2003 & 1.0 & 0.5 & 1.0 & 0.5 \\
\hline 2004 & 1.0 & 0.5 & 1.0 & 0.5 \\
\hline 2005 & 1.0 & 0.5 & 1.0 & 0.5 \\
\hline 2006 & 1.0 & 0.5 & 1.0 & 0.5 \\
\hline 2007 & 1.0 & 0.4 & 1.0 & 0.5 \\
\hline 2008 & 0.0 & 0.0 & 1.0 & 0.5 \\
\hline 2009 & 0.0 & 0.0 & 1.0 & 0.5 \\
\hline 2010 & 0.0 & 0.0 & 1.0 & 0.5 \\
\hline 2011 & 0.0 & 0.0 & 1.0 & 0.5 \\
\hline 2012 & 0.0 & 0.0 & 1.0 & 0.5 \\
\hline 2013 & 0.0 & 0.0 & 1.0 & 0.5 \\
\hline
\end{tabular}

* In 1991 and 1992, there was a temporary tax on commercial premises.

Note: Since 1996, there has also been a tax on hydroelectric power stations and wind turbines, which is not shown in the table.

Source: Skatteverket (2013), Öberg (2008). 
Table 6. Local real estate fee, 2008-2013 (SEK).

\begin{tabular}{|c|c|c|}
\hline Year & $\begin{array}{r}\text { Owner-occupied } \\
\text { houses } \\
\end{array}$ & Apartment buildings \\
\hline \multirow{2}{*}{2008} & $0.75 \%$, & $0.4 \%$, \\
\hline & $\max 6.000$ & max 1.200/apartment \\
\hline \multirow{2}{*}{2009} & $0.75 \%$, & $0.4 \%$, \\
\hline & $\max 6.362$ & $\max 1.272$ /apartment \\
\hline \multirow{2}{*}{2010} & $0.75 \%$ & $0.4 \%$, \\
\hline & $\max 6.387$ & max 1.277/apartment \\
\hline \multirow{2}{*}{2011} & $0.75 \%$, & $0.4 \%$, \\
\hline & $\max 6.512$ & max 1.302/apartment \\
\hline \multirow{2}{*}{2012} & $0.75 \%$ & $0.4 \%$, \\
\hline & $\max 6.825$ & max 1.365/apartment \\
\hline \multirow{2}{*}{2013} & $0.75 \%$ & $0.3 \%$, \\
\hline & $\max 7.074$ & $\max 1.210$ /apartment \\
\hline
\end{tabular}

Source: Skatteverket (2013).

Table 7. The most important tax reforms for real estate.

\begin{tabular}{ll}
\hline Year & \\
\hline 1862 & Appropriation tax with imputed income \\
1911 & Conventional method, introduced at the state level \\
1920 & Guaranteed tax system, introduced at the local level \\
1954 & Introduction of the so-called villaschablon \\
1985 & Introduction of a specific real estate tax at the state level \\
1990 & Simplifications of the system as part of a comprehensive tax \\
& reform \\
& Part of the real estate tax transformed to a "local fee"
\end{tabular}

\section{The aggregate importance of real estate taxation}

Inasmuch as the real estate tax was often an integral part of the ordinary income tax system (which was often progressive), public and official statistics have not always reported the amount of revenue emanating from real estate taxation. The issue is further complicated by the fact that within the local guaranteed tax system, the entire amount paid in real estate tax 
was not effective, i.e., a portion of the revenue would have been generated anyway. ${ }^{35}$ Unadjusted figures would therefore be inherently misleading. Often explicit information on tax revenue from the taxation of real estate cannot be obtained, and one must rely on rough estimations (SOU 1942:34, 311).

During the first period examined, before the local guaranteed tax system was introduced in 1920, explicit figures on the basic tax and the specific urban real estate tax can be found. As shown in Table 8, the basic tax was an important revenue source for the state during the 1860s and 1870s. The share of the basic tax of total state tax revenue was approximately 20 percent, and its share of GDP was at most approximately one percent. However, the importance of the basic tax declined quickly during the few decades that followed, and the basic tax was a negligible source of state income by the early part of the twentieth century.

Table 8. Basic tax.

\begin{tabular}{lrrr}
\hline Year & $\begin{array}{r}\text { Amount } \\
\text { (thousands) }\end{array}$ & $\begin{array}{r}\text { Share of state } \\
\text { tax revenues }\end{array}$ & $\begin{array}{r}\text { Taxes as share } \\
\text { of GDP }\end{array}$ \\
\hline 1862 & 7,398 & 23.0 & 1.0 \\
1870 & 7,487 & 19.0 & 0.8 \\
1880 & 6,770 & 11.5 & 0.5 \\
1890 & 5,237 & 7.0 & 0.4 \\
1900 & 1,696 & 1.5 & $<0.1$ \\
1910 & 21 & 0.0 & $<0.1$ \\
1920 & 1,698 & 0.2 & $<0.1$ \\
\hline
\end{tabular}

Note: The basic tax also includes taxes associated with the allotted military system. All amounts in the tables refer to SEK.

Source: Statistics Sweden (1914a, 1923a) and own calculations.

The importance of the urban real estate tax was minor (not shown in any table). In 1875, approximately half of the urban municipalities (47 of 96) used this tax. At the aggregate level, the tax revenue raised corresponded to approximately three percent of urban municipalities' total local revenue. The importance of the urban real estate tax diminished throughout the 1800s and early 1900s. By 1900, only 17 urban municipalities used this tax, and it corresponded to a miniscule 0.2 percent of the total local revenue of urban municipalities. The tax rate for the urban real estate tax varied greatly among the municipalities, and for some municipalities, its importance for local revenue was somewhat greater. In 1900, the tax rate varied between 0.45 percent of agricultural property value (in Karlstad) and 0.01 percent of

\footnotetext{
${ }^{35} \mathrm{Cf}$. the discussion in section 3 about the local guaranteed tax system.
} 
property value (in Ronneby). ${ }^{36}$ The tax rate in Stockholm fluctuated at approximately 0.1 percent, and its share of local revenue decreased from five percent in 1875 to almost zero at the outbreak of World War I.

Information on the extent and importance of the income tax during this time, which added part of the value of the property to the taxable income as a form of imputed income, is difficult to find. Data on total income tax revenue are widely available; however, the proportion related to real estate is not reported separately.

One way to illustrate the importance of real estate taxation is to analyze the assessed value of real estate or the taxable income (tax base) derived from the imputed income on real estate. ${ }^{37}$ The estimated tax on the imputed income can then be related to other revenues/taxes at the state or local level. This procedure generates a proxy for the importance of the taxation of real estate. The results are presented in Tables 9 and 10.

At the state level, the results through 1910, when a conventional system was implemented, are presented in Table 9. At the state level, approximately one-third of income tax revenue came from imputed income on real estate. However, income tax was not an important source of revenue at the state level at this point in time, and its estimated value, including all state revenue (taxes), was minor (at most a mere two to three percent).

Table 9. Estimated importance of real estate income tax, state level.

\begin{tabular}{rrr}
\hline Year & $\begin{array}{r}\text { Share of state } \\
\text { income taxes }\end{array}$ & $\begin{array}{r}\text { Share of state } \\
\text { revenues }\end{array}$ \\
\hline 1862 & 38 & 2.5 \\
1870 & 37 & 2.0 \\
1880 & 33 & 3.0 \\
1890 & 31 & 2.0 \\
1900 & 32 & 2.5 \\
1910 & 29 & 2.5
\end{tabular}

Note: State revenues refer to all state taxes. Rounded figures. Source: Statistics Sweden (1914a) and own calculations.

Table 10 presents the results at the local level until 1920, when the local guaranteed tax system was first introduced. At the local level, a meaningful distinction can be made between rural and urban municipalities (landskommuner and stadskommuner). Unfortunately, no data at the local level are available until approximately 1880. Data as a share of income taxes are

\footnotetext{
${ }^{36}$ The tax rate normally varied between very low levels, from a low of 0.004 percent, to at most one percent.

${ }^{37}$ For the local level, the imputed income is available but, the tax rate, which differs among municipalities, is not. At the state level, the assessed value of real estate is available and can be used to derive the imputed income.
} 
also presented for the period from 1920 to 1950 . However, as described above, these data may be misleading because of the construction of the system, as part of these taxes would have been paid even if the real estate tax had been abolished. In urban municipalities, approximately one-fifth of income tax revenue came from imputed real estate income, representing approximately five to ten percent of total local revenue. In rural municipalities, up to two-thirds of income tax came from imputed real estate income, representing approximately one-fourth of total revenue. Collectively, approximately 30 to 40 percent of local income tax revenue came from real estate, representing approximately ten to 15 percent of total local revenue until 1920. Hence, the available evidence suggests that the real estate tax was more important at the local than at the state level and more important in rural than in urban municipalities. ${ }^{38}$

Table 10. Estimated importance of real estate income tax, local level.

\begin{tabular}{|c|c|c|c|c|c|c|}
\hline & \multicolumn{2}{|c|}{ All municipalities } & \multicolumn{2}{|c|}{ Urban municipalities } & \multicolumn{2}{|c|}{ Rural municipalities } \\
\hline Year & $\begin{array}{r}\text { Share of local } \\
\text { income tax } \\
\text { revenues }\end{array}$ & $\begin{array}{r}\text { Share of local } \\
\text { revenues }\end{array}$ & $\begin{array}{r}\text { Share of local } \\
\text { income tax } \\
\text { revenues }\end{array}$ & $\begin{array}{r}\text { Share of local } \\
\text { revenues }\end{array}$ & $\begin{array}{r}\text { Share of local } \\
\text { income tax } \\
\text { revenues }\end{array}$ & $\begin{array}{r}\text { Share of local } \\
\text { revenues }\end{array}$ \\
\hline 1881 & 43 & 15.0 & 19 & 5.5 & $66^{*}$ & $28.0^{*}$ \\
\hline 1890 & 42 & 15.5 & 22 & 7.0 & 64 & 28.0 \\
\hline 1900 & 34 & 14.0 & 19 & 6.5 & 52 & 26.0 \\
\hline 1910 & 28 & 13.0 & 19 & 7.5 & 44 & 24.0 \\
\hline 1920 & 14 & - & 8 & - & 23 & - \\
\hline 1931 & 20 & - & 14 & - & 30 & - \\
\hline 1940 & 18 & - & 15 & - & 23 & - \\
\hline 1950 & 11 & - & 10 & - & 12 & - \\
\hline
\end{tabular}

Note: * Only including agricultural property. Local revenues refer to all local taxes, state subsidies, and fees. The tax systems at the rural level are not completely comparable before and after 1910. Rounded figures. Source: Statistics Sweden (1920b), Statistics Sweden (1923a), SOU 1953:8 and own calculations.

During the first half of the twentieth century, the importance of local real estate taxation seemed to diminish, as the estimated share of income taxes decreased. For the 1946-1953 period, explicit statistics concerning local real estate taxes can also be found (see Table 11). The share of the real estate tax represented ten to 15 percent of local income tax revenue and approximately 0.5 to 1.0 percent of GDP. However, note that from 1920 onward, the local

\footnotetext{
${ }^{38}$ As described above, a specific real estate tax may also exist in urban municipalities. However, even if this type of tax is accounted for, real estate taxation was generally more important in rural municipalities.
} 
guaranteed tax system was in place, and as these figures do not take into account the effective tax rate, they give only an upper bound of the importance of this real estate tax.

Table 11. Real estate tax at the local level (unadjusted figures).

\begin{tabular}{lrrr}
\hline Year & $\begin{array}{r}\text { Amount } \\
\text { (million) }\end{array}$ & $\begin{array}{r}\text { Share of local } \\
\text { income tax } \\
\text { revenues } \\
\%\end{array}$ & Share of GDP \\
\hline 1946 & 153.8 & 15 & 0.7 \\
1947 & 162.0 & 11 & 0.6 \\
1948 & 168.6 & 11 & 0.6 \\
1949 & 175.4 & 10 & 0.6 \\
1950 & 187.8 & 11 & 0.5 \\
1951 & 190.5 & 11 & 0.5 \\
1952 & 298.9 & 13 & 0.7 \\
1953 & 361.5 & 13 & 0.8 \\
\hline
\end{tabular}

Source: Statistics Sweden (1947c-1954c) and own calculations.

Fortunately, some archival reports have analyzed the importance of the local guaranteed tax system in more detail and have estimated the effective tax rate based on thorough analyses of a subsample of the municipalities (e.g., SOU 1942:34, SOU 1953:8, SOU 1960:4). These measures of the "effective" amount raised were made for the years 1952, 1957 and 1958 (see Table 12). ${ }^{39}$ The amount for 1952 (SEK 155.2 million) can be compared with the unadjusted amount in Table 11 (SEK 298.9 million), implying an overall effective rate of approximately 50 percent. ${ }^{40}$ The share of GDP was minor. Adding further insight into the importance of the real estate tax, the reports estimated how much the taxable income would have decreased if the local real estate tax were abolished. They also estimated how much the local tax rate needed to increase to compensate for this shortfall. These counterfactual estimates can also be found for the 1930s. As the table shows, taxable income would have decreased, for example, by 28 percent in 1933 if the local real estate tax had been abolished. To compensate for this shortfall, the local tax rate had to increase by 4.48 percentage points (that is, almost by one half) if tax revenue were to remain constant (on average). ${ }^{41}$

\footnotetext{
${ }^{39}$ The effective amount refers to revenue directly results from the real estate tax, that is, revenue that would disappear if the real estate tax were abolished.

${ }^{40}$ In SOU 1953:8, the effective rate in 1952 is estimated to be $20-25$ percent on agricultural property and 65-70 percent on other types of properties.

${ }^{41}$ The average local tax rate was then approximately ten percent.
} 
Table 12. Real estate tax at the local level (adjusted figures) and the importance of the local real estate tax during the guaranteed tax system.

\begin{tabular}{lrrrr}
\hline & \multicolumn{2}{c}{$\begin{array}{c}\text { Estimated effective } \\
\text { local real estate tax }\end{array}$} & \multicolumn{2}{c}{$\begin{array}{c}\text { The importance of the } \\
\text { local real estate tax }\end{array}$} \\
\hline Year & $\begin{array}{r}\text { Amount } \\
\text { (million) }\end{array}$ & Share of GDP & $\begin{array}{r}\text { Decrease of } \\
\text { taxable income } \\
(\%)\end{array}$ & $\begin{array}{r}\text { Corresponding local } \\
\text { income tax increase } \\
\text { (percentage points) }\end{array}$ \\
\hline 1933 & - & - & 28.1 & 4.48 \\
1936 & - & - & 13.6 & 1.43 \\
1950 & - & - & 4.1 & 0.28 \\
1952 & 155.2 & 0.3 & 6.6 & 0.58 \\
1957 & 166.1 & 0.3 & 4.4 & - \\
1958 & 130.0 & 0.2 & 2.8 & 0.31 \\
1972 & 813 & 0.4 & 3.5 & - \\
1975 & $1.082-1.298$ & $0.3-0.4$ & 3.8 & - \\
\hline
\end{tabular}

Note: During the 1930s and 1950s, the average local tax rates were approximately ten and 12 percent, respectively. The figures on tax increases refer only to the local level and exclude the county level. At the county level, the (effective) real estate tax is estimated to correspond to a local income tax increase of approximately 0.29 in 1952 and 0.125 in 1958. Figures concerning taxable income (column 4) in 1972 and 1975 are not presented in the SOUs but are calculated separately based on the local taxable income.

Source: SOU 1942:34, SOU 1953:8, SOU 1960:4, SOU 1973:4, SOU 1979:32, SOU 1986:6 and own calculations.

The table shows marked differences among the years examined. Some of the differences can be explained by the influence of the business cycle. During recessions, the real estate tax is binding for a greater number of property owners, and its importance increases. ${ }^{42}$ Although the tax rate may vary over the business cycle, there is a clearly decreasing trend in the importance of the real estate tax. By 1958, the required tax increase had decreased sharply to 0.31 percentage points.

Substantial differences also existed among municipalities because the amount and composition of real estate in the municipalities varied considerably. The required tax increase, if the real estate tax were abolished, varied from 0.15 to 1.30 in the subsample examined for the year 1952. ${ }^{43}$ Estimations for the urban municipalities Norrtälje and Stockholm show that the effective real estate tax corresponded to a local income tax increase of 0.95 and 0.70 percentage points, respectively. ${ }^{44}$

\footnotetext{
${ }^{42}$ Hence, the depression of the 1930s greatly increased the importance of the real estate tax in 1933, which was initially one of the cardinal reasons behind the construction of the real estate tax. The real estate tax should provide the local authorities with a stable tax source; when ordinary taxes decreased, the importance of the real estate tax increased.

${ }^{43}$ The smallest increase was found in the district of Nysätra, a small agricultural district in the northern county of Västerbotten. The largest increase was found in the district of Bara in Skåne, Sweden’s southernmost county.

${ }^{44}$ The average local tax rate was approximately 12 percent at the time. There were still municipalities where the real estate tax played an important role, even in the 1950s. A separate analysis of the district of Djurö in 1952, a
} 
As shown in Table 12, the local real estate tax appears to have been important in the 1930s, especially during recessions; however, its importance in the 1950s appears to be minor. For approximately 80 percent of rural municipalities, the real estate tax represented less than 20 percent of the income tax in 1952 even without adjustments for the effective rate. The revenue from the real estate tax was as high as 35-45 percent of income tax revenue in at most six of more than 900 rural municipalities (no urban municipalities had a revenue share this high). In 1958, 871 rural municipalities and all urban municipalities had a share below 15 percent. In 1952, 16 municipalities had a tax income share that exceeded 30 percent. In 1958, this number had decreased to four.

Estimates of the effective real estate tax during the 1970s are also available (SOU 1973:4, SOU 1979:32). These estimates suggest that the importance of the real estate tax was still rather low, although its share of GDP appears to have slightly increased. The effective rate was estimated to be 20 percent for agricultural property, 75 percent for owner-occupied houses, 75 percent for apartment buildings and business buildings, and 20 percent for industrial property. ${ }^{45}$

The introduction of a distinct real estate tax — which was not integrated with the income tax-at the state level in the mid-1980s increased the availability of more precise information on the importance of the real estate tax. ${ }^{46}$ Table 13 and Figure 1 depict the evolution of the importance of the real estate tax. Initially, when the tax only referred to the fee on apartment buildings, its importance was modest, constituting a small share of GDP and state tax revenue (0.1 and 0.3 percent, respectively). Its importance gradually increased during the 1990 s, when it reached and occasionally exceeded one percent of GDP. As a share of state tax revenue, real estate tax revenue peaked at approximately five percent. When part of the state tax was transformed into a "local fee", the amount raised and the tax share were more than halved. ${ }^{47}$ However, when the local real estate fee is accounted for, the total amount raised as real estate tax/fee and its share of GDP remained almost at the same level. ${ }^{48}$ In 2013, the public sector collected approximately SEK 30 billion in real estate tax, which represented approximately

small district in the Stockholm archipelago with mostly summer residences, shows that abolishing the local real estate tax would require an increase of the local income tax by up to 3.4 percentage points. By 1958, this number had decreased to 1.29 percentage points.

${ }^{45}$ In SOU 1986:6, the effective tax amount raised was estimated, but only for natural persons. The estimated amount was SEK 1.354 million, which corresponded to less than 0.2 percent of GDP.

${ }^{46}$ The imputed income in 1982 on owner-occupied houses (villaschablon) was approximately SEK seven billion, according to SOU 1992:11. To calculate the tax revenues raised from this imputed income, one must have information on the marginal tax rates of the property owners. See also Table 14.

${ }^{47}$ The state also reduced its subsidies to the local governments by the same amount as the "local fee" generated.

${ }^{48}$ At the state level, to compensate for this change, the capital gains tax on private residences was also increased from 20 to 22 percent. The possibility of postponing capital gains tax was also reduced. 
0.8 percent of GDP. This figure can be compared with the state income tax, which generated approximately SEK 40 billion, or the wealth tax, which generated approximately SEK five billion annually before it was finally abolished in 2007 (Du Rietz and Henrekson 2015).

Table 13. The state real estate tax and local real estate fee.

\begin{tabular}{|c|c|c|c|c|c|c|}
\hline \multirow[b]{2}{*}{ Year } & \multicolumn{3}{|c|}{ Real estate state tax } & \multicolumn{3}{|c|}{ Local real estate fee } \\
\hline & $\begin{array}{l}\text { Amount } \\
\text { (billion) }\end{array}$ & $\begin{array}{r}\text { Share of state } \\
\text { tax revenue } \\
\%\end{array}$ & $\begin{array}{r}\text { Share of GDP } \\
\%\end{array}$ & $\begin{array}{l}\text { Amount } \\
\text { (billion) }\end{array}$ & $\begin{array}{r}\text { Share of local } \\
\text { tax revenue } \\
\%\end{array}$ & $\begin{array}{r}\text { Share of GDP } \\
\%\end{array}$ \\
\hline 1985 & 0.68 & 0.3 & 0.1 & - & - & - \\
\hline 1986 & 0.95 & 0.4 & 0.1 & - & - & - \\
\hline 1987 & 3.6 & 1.3 & 0.3 & - & - & - \\
\hline 1988 & 4.6 & 1.6 & 0.4 & - & - & - \\
\hline 1989 & 5.8 & 1.8 & 0.5 & - & - & - \\
\hline 1990 & 6.0 & 1.7 & 0.4 & - & - & - \\
\hline 1991 & 6.0 & 1.7 & 0.4 & - & - & - \\
\hline 1992 & 8.5 & 2.5 & 0.5 & - & - & - \\
\hline 1993 & 16.1 & 5.0 & 1.0 & - & - & - \\
\hline 1994 & 16.9 & 5.4 & 1.0 & - & - & - \\
\hline 1995 & 14.4 & 3.4 & 0.8 & - & - & - \\
\hline 1996 & 14.9 & 2.7 & 0.8 & - & - & - \\
\hline 1997 & 15.3 & 2.7 & 0.8 & - & - & - \\
\hline 1998 & 24.0 & 3.8 & 1.2 & - & - & - \\
\hline 1999 & 27.1 & 4.0 & 1.3 & - & - & - \\
\hline 2000 & 24.8 & 3.7 & 1.1 & - & - & - \\
\hline 2001 & 23.3 & 3.4 & 1.0 & - & - & - \\
\hline 2002 & 23.3 & 3.5 & 1.0 & - & - & - \\
\hline 2003 & 21.2 & 3.5 & 0.8 & - & - & - \\
\hline 2004 & 23.5 & 3.7 & 0.9 & - & - & - \\
\hline 2005 & 24.0 & 3.5 & 0.9 & - & - & - \\
\hline 2006 & 25.0 & 3.1 & 0.8 & - & - & - \\
\hline 2007 & 25.9 & 3.1 & 0.8 & - & - & - \\
\hline 2008 & 11.5 & 1.5 & 0.4 & 12.4 & 3.7 & 0.4 \\
\hline 2009 & 11.3 & 1.5 & 0.4 & 14.1 & 4.0 & 0.5 \\
\hline 2010 & 11.9 & 1.5 & 0.4 & 14.5 & 4.3 & 0.4 \\
\hline 2011 & 12.7 & 1.6 & 0.4 & 14.8 & 4.4 & 0.4 \\
\hline 2012 & 12.8 & 1.7 & 0.4 & 15.9 & 4.3 & 0.4 \\
\hline 2013 & 14.9 & 1.9 & 0.4 & 15.9 & 4.1 & 0.4 \\
\hline
\end{tabular}

Note: 1985,1986 refers to the fee on apartment buildings. The state cut its subsidies to the local governments by the same amount as the "local fee" generated.

Source: Ekonomistyrningsverket (2014a) and own calculations. 
Figure 1. The state real estate tax, 1985-2013 (\%).

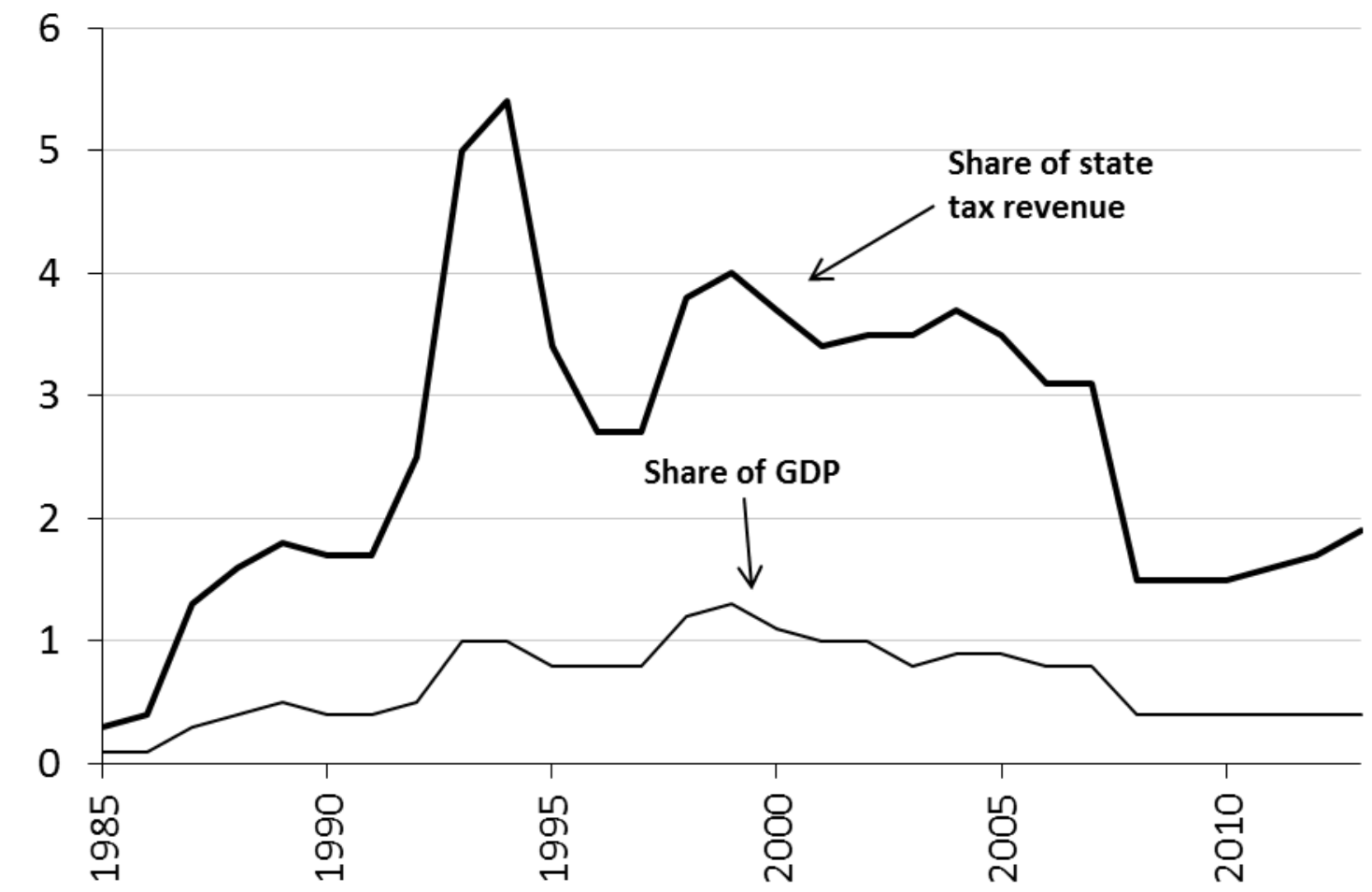

Note: See Table 13.

Source: See Table 13.

The above statistics give the gross revenue generated by the real estate tax. However, interest expenses on household mortgages are tax deductible. Consequently, accounting for these tax deductions provides a "net” figure for the taxation of real estate. Data on net figures are difficult to find. However, Table 14 presents some interesting estimations for the 1980s, called "tax subsidies on owner-occupied housing". These subsidies include the effect of tax deductions on household mortgage loans, reduced by the tax revenue from the imputed income on owner-occupied houses (villaschablon). As a share of GDP, these estimated subsidies correspond to approximately 1.2-1.6 percent of GDP; thus, they are quite large. These figures are higher than the total amount raised through the real estate tax during the late 1980s (depicted in Table 13 and including legal entities). Hence, when the effect from deductible interest expenses is included, the state did not generate any tax revenue from owner-occupied houses. Table 15 shows the estimated tax reductions due to deductibility of interest expenses on household mortgage loans after the 1990-1991 tax reform. ${ }^{49}$ Normally,

\footnotetext{
${ }^{49}$ During the 1980s, the scope of deductions was gradually reduced (in 1979, deductions could be above 85 percent), and in principle, the tax could be reduced by a maximum of approximately 50 percent of the interest paid in 1985. After the 1990-1991 tax reform, the tax could be reduced by 30 percent of the interest paid up to SEK 100,000 and 21 percent above this level. All types of interest, not just interest on mortgage loans, were and still are (as of 2014) deductible. Information on interest deductions that relates only to mortgages cannot be found in the official statistics, but they can be estimated.
} 
the estimated tax reductions range between SEK 15 and 20 billion. When these reductions are accounted for, the net amount, including all real estate taxes, was zero during the early 1990s. When the tax rates increased and when commercial premises and industrial properties were also taxed, the net amount increased. During the 2000s, the net amount decreased but remained positive. ${ }^{50}$

Table 14. Tax subsidies on owner-occupied housing.

\begin{tabular}{rrr}
\hline Year & $\begin{array}{r}\text { Amount } \\
\text { (billion) }\end{array}$ & \% of GDP \\
\hline 1980 & 7.9 & 1.4 \\
1981 & 9.9 & 1.6 \\
1982 & 10.3 & 1.5 \\
1983 & 10.9 & 1.4 \\
1984 & 10.7 & 1.2 \\
1985 & 13.0 & 1.4 \\
1986 & 13.2 & 1.3 \\
1987 & 13.8 & 1.3 \\
1988 & 15.9 & 1.3 \\
\hline
\end{tabular}

Note: The subsidies include tax reductions on household mortgage loans, reduced by the tax revenues from the imputed income on owner-occupied houses (villaschablon).

Source: SOU 1989:33 and Regeringens proposition 1987/88:100, bilaga 13.

\footnotetext{
${ }^{50}$ When only owner-occupied housing is considered, the estimated net tax was still negative at the beginning of the 1990s. It was also negative during the 2000s. To completely analyze the real estate sector, one can also include the effects of housing and interest allowances; however, such an analysis is beyond the scope of this paper.
} 
Table 15. Estimated tax reductions due to interest expenses on household mortgage loans (billion SEK).

\begin{tabular}{|c|c|c|c|}
\hline Year & Interest expenses & $\begin{array}{r}\text { Estimated } \\
\text { interest expenses } \\
\text { on mortgage loans } \\
\end{array}$ & $\begin{array}{r}\text { Estimated } \\
\text { tax reductions }\end{array}$ \\
\hline 1991 & 85 & 64 & 19 \\
\hline 1992 & 91 & 68 & 21 \\
\hline 1993 & 84 & 63 & 19 \\
\hline 1994 & 77 & 58 & 17 \\
\hline 1995 & 74 & 56 & 17 \\
\hline 1996 & 70 & 53 & 16 \\
\hline 1997 & 60 & 45 & 14 \\
\hline 1998 & 56 & 42 & 13 \\
\hline 1999 & 53 & 40 & 12 \\
\hline 2000 & 56 & 42 & 13 \\
\hline 2001 & 61 & 46 & 14 \\
\hline 2002 & 65 & 49 & 15 \\
\hline 2003 & 66 & 49 & 15 \\
\hline 2004 & 63 & 47 & 14 \\
\hline 2005 & 62 & 46 & 14 \\
\hline 2006 & 65 & 49 & 15 \\
\hline 2007 & 83 & 62 & 19 \\
\hline 2008 & 106 & 79 & 24 \\
\hline 2009 & 80 & 60 & 18 \\
\hline 2010 & 72 & 54 & 16 \\
\hline 2011 & 102 & 77 & 23 \\
\hline 2012 & 110 & 83 & 25 \\
\hline
\end{tabular}

Note: Based on Statistics Sweden (2010d), interest expenses on mortgage loans are estimated to be 75 percent of total interest expenses. Tax reductions are estimated to be 30 percent of interest expenses on mortgage loans. Source: Ekonomistyrningsverket (2012, 2014b), Statistics Sweden (2010d) and own calculations. 


\section{Other taxes on real estate}

Other taxes have also been levied on real estate, although they are not explicitly defined as real estate taxes. First, a stamp duty (stämpelskatt) is payable when one buys real estate or acquires a mortgage. The tax has changed frequently, and temporary forms of relief have been implemented. ${ }^{51}$

The stamp duty has a long history that can be traced back to at least the late seventeenth century. Originally, to be legally binding, some transactions had to be written on specific documents provided by the state. Later, specific "stamps" had to be purchased and attached to legal documents to be valid. In addition to real estate-related transactions, these stamps have historically been required on several types of documents, e.g., shares, bonds, lottery tickets, passports, and drivers' licenses. ${ }^{52}$ Part of the tax can be viewed as a fee that covers the expense of providing the economy with standardized certificates and permits.

Table 16 shows that the stamp duty began to grow in importance with respect to tax revenue toward the end of the nineteenth century when the basic tax was abolished. In 1910, approximately ten percent of state tax revenue came from this tax, amounting to approximately 0.5 percent of GDP. After World War II, its importance for tax revenue declined sharply, with the exception of the years around 1990, when its importance temporarily increased. By 2010, the importance of the stamp duty for state tax revenue was slightly less than that of the remaining state real estate tax. ${ }^{53}$

The so-called excise duty on forestry (skogsaccis) was a local tax that was implemented following a law enacted in 1909 and abolished in 1947. The amount raised by this tax varied among municipalities, depending on the prevalence of forestry in the municipality. On average, this excise duty contributed less than one percent of total local government revenues, having little importance. Its share of GDP was likewise minor (below 0.1 percent).

\footnotetext{
${ }^{51}$ The tax was 1.5 percent of the purchase sum (legal entities paid three percent before 2011 and 4.25 percent after 2011) and two percent on a mortgage loan (Skatteverket 2013).

${ }^{52}$ Even products have occasionally required stamps, such as the stamp duty on punsch (a sweet arrack-based liqueur). However, this tax is regarded as a separate tax.

${ }^{53}$ See SOU 1983:8 for more information about the stamp duty.
} 
Table 16. Stamp duty.

\begin{tabular}{rrrr}
\hline Year & $\begin{array}{r}\text { Amount } \\
\text { (million) }\end{array}$ & $\begin{array}{r}\text { Share of state } \\
\text { tax revenue, \% }\end{array}$ & $\begin{array}{r}\text { Share of GDP } \\
\%\end{array}$ \\
\hline 1862 & 1.9 & 5.7 & 0.17 \\
1870 & 1.4 & 3.6 & 0.13 \\
1880 & 3.2 & 5.4 & 0.21 \\
1890 & 3.5 & 4.8 & 0.21 \\
1900 & 6.6 & 6.3 & 0.27 \\
1910 & 15.6 & 10.0 & 0.44 \\
1920 & 60.1 & 7.8 & 0.46 \\
1930 & 56.8 & 9.5 & 0.59 \\
1940 & 49.1 & 3.1 & 0.34 \\
1950 & 52.7 & 1.0 & 0.16 \\
1960 & 103 & 0.7 & 0.14 \\
1970 & 253 & 0.6 & 0.13 \\
1980 & 1,221 & 0.9 & 0.21 \\
1990 & 7,406 & 2.1 & 0.50 \\
2000 & 4,878 & 0.7 & 0.22 \\
2010 & 8,968 & 1.1 & 0.27 \\
2013 & 8,913 & 1.1 & 0.24 \\
\hline Source: Stis & & &
\end{tabular}

Source: Statistics Sweden (1914a-2002a), Ekonomistyrningsverket (2014a) and own calculations.

\section{Conclusions}

This paper has analyzed the evolution of real estate taxation in Sweden from 1862 to 2013. Fully documenting and evaluating the importance of real estate taxation in Sweden is not feasible because of the limited availability of data in historical records and the sheer complexity of the tax system. Some general conclusions can nevertheless be drawn.

An imputed income based on property value was added to taxable income at the state and local levels until 1910 and 1920, respectively. Although tax on this income was not the most important component of tax revenue, it was more important at the local than at the state level and in rural than in urban municipalities. In 1900, approximately 25 percent of the total local revenue in rural municipalities came from this real estate tax. During the 1860s and 1870s, the so-called basic tax was also an important source of tax revenue at the state level (corresponding to approximately 20-25 percent of total state tax revenue). The importance of the basic tax for state tax revenue subsequently diminished sharply in the late nineteenth century. 
In 1920, the tax system was reformed, and a complex "guaranteed” tax system providing the municipalities with a stable tax base was introduced. The real estate tax was an important component of this new system, particularly during downturns and depressions. Estimations show that the real estate tax could still significantly influence the tax base; however, its importance for tax revenue declined substantially after World War II. While the tax system was reformed in the 1950s, the principles behind taxation remained largely unchanged. A formal imputed income on owner-occupied houses was also introduced.

In the mid-1980s, a separate state real estate tax was introduced. With the 1990-1991 tax reform, the construction of the real estate tax was simplified, and all other forms of real estate taxation were abolished. This tax contributed two to four percent of total state tax revenue and approximately one percent of GDP. In 2008, part of the tax was transformed into a local fee. When tax-deductible interest expenses are accounted for, net revenue from real estate taxation of owner-occupied houses was strongly negative in the 1980s. After the 1990-1991 tax reform, the net revenue increased initially but decreased during the 2000s. 


\section{References}

Andersson, Staffan, John Bratt and Stefan Svensson (1985). Deklaration och beskattning. Skatterna på inkomst och förmögenhet, arv, gåva m.m. 31 reviderade upplagan. Stockholm: Norstedts.

Bratt, John (1989). Deklaration och beskattning. Skatterna på inkomst och förmögenhet, arv, gåva m.m. 35 reviderade upplagan. Stockholm: Norstedts.

Bratt, John and Olle Fernström (1978). Deklaration och beskattning. Skatterna på inkomst och förmögenhet, arv, gåva m.m. 23 reviderade upplagan. Stockholm: Norstedts.

Bratt, John and Olle Fernström (1979). Deklaration och beskattning. Skatterna på inkomst och förmögenhet, arv, gåva m.m. 24 reviderade upplagan. Stockholm: Norstedts.

Bratt, John and Olle Fernström (1981). Deklaration och beskattning. Skatterna på inkomst och förmögenhet, arv, gåva m.m. 27 reviderade upplagan. Stockholm: Norstedts.

Bratt, John and Stephan Tolstoy (1986). Deklaration och beskattning. Skatterna på inkomst och förmögenhet, arv, gåva m.m. 32 reviderade upplagan. Stockholm: Norstedts.

Bratt, John and Stephan Tolstoy (1988a). Deklaration och beskattning. Skatterna på inkomst och förmögenhet, arv, gåva m.m. 33 reviderade upplagan. Stockholm: Norstedts.

Bratt, John and Stephan Tolstoy (1988b). Deklaration och beskattning. Skatterna på inkomst och förmögenhet, arv, gåva m.m. 34 reviderade upplagan. Stockholm: Norstedts.

Ds 1998:3. Fastighetsskatt-alternativa underlag m.m. Stockholm: Fritzes.

Du Rietz, Gunnar and Magnus Henrekson (2015). "Swedish Wealth Taxation (1911-2007).” IFN Working Paper nr 1000, published as chapter 6, pp. 267-302 in Swedish Taxation: Developments since 1862, edited by Magnus Henrekson and Mikael Stenkula. New York: Palgrave Macmillan.

Du Rietz, Gunnar, Dan Johansson and Mikael Stenkula (2015). "Swedish Labor Income Taxation (1862-2013).” IFN Working Paper nr 977, published as chapter 2, pp. 35-122 in Swedish Taxation: Developments since 1862, edited by Magnus Henrekson and Mikael Stenkula. New York: Palgrave Macmillan.

Eberstein, Gösta (1929). Om skatt till stat och kommun enligt svensk rätt: Förra delen. Stockholm: Norstedts.

Eberstein, Gösta (1937). Om skatt till stat och kommun enligt svensk rätt: Senare delen. Stockholm: Norstedts.

Ekonomistyrningsverket (2012). Prognos statens budget och de offentliga finanserna. September 2012. ESV 2012:37. Stockholm: Ekonomistyrningsverket [Swedish National Financial Management Authority].

Ekonomistyrningsverket (2014a). Tidsserier, statens budget m.m. 2013. ESV 2014:41. Stockholm: Ekonomistyrningsverket [Swedish National Financial Management Authority].

Ekonomistyrningsverket (2014b). Prognos statens budget och de offentliga finanserna. Juni 2014. ESV 2014:40. Stockholm: Ekonomistyrningsverket [Swedish National Financial Management Authority].

Gårestad, Peter (1987). Industrialisering och beskattning i Sverige 1861-1914. Doctoral thesis in Economic History, Department of Economic History, Uppsala University. Stockholm: Almqvist \& Wiksell International.

Löwnertz, Susanne (2003). De svenska skatternas historia. Stockholm: Riksskatteverket. Regeringens proposition 1987/88:100, bilaga 13. Förslag till statsbudget för budgetåret 1988/89.

Skatteverket (2013). Tax Statistical Yearbook of Sweden 2013. Stockholm: Skatteverket [Swedish Tax Agency]. 
SOU 1942:34. Betänkande med förslag till omläggning av den kommunala beskattningen m.m. Stockholm: Finansdepartementet.

SOU 1953:8. Utredning om fastighetsbeskattningen. Stockholm: Nordiska bokhandeln.

SOU 1960:4. Fastighetsbeskattningen: betänkande. Stockholm: Finansdepartementet.

SOU 1973:4. Fastighetstaxering: betänkande. Stockholm: Finansdepartementet.

SOU 1974:16. Bostadsbeskattning. Del 1. Neutral bostadsbeskattning. Stockholm:

Liber/Allmänna förlaget.

SOU 1976:11. Bostadsbeskattning. Del 2. Slutbetänkande. Stockholm: Liber/Allmänna förlaget.

SOU 1979:32. Fastighetstaxering 81: betänkande. Stockholm: Liber/Allmänna förlaget.

SOU 1983:8. Stämpelskatt: betänkande. Stockholm: Liber/Allmänna förlaget.

SOU 1986:4. Bostadskommitténs slutbetänkande. Sammanfattning. Stockholm:

Liber/Allmänna förlaget.

SOU 1986:5. Bostadskommitténs slutbetänkande. Del 1. Stockholm: Liber/Allmänna förlaget.

SOU 1986:6. Bostadskommitténs slutbetänkande. Del 2. Stockholm: Liber/Allmänna förlaget.

SOU 1989:33. Reformerad inkomstbeskattning. Stockholm: Allmänna förlaget.

SOU 1992:8. Fastighetstaxering m.m. - bostadsrätter: betänkande. Stockholm: Allmänna förlaget

SOU 1992:11. Fastighetsskatt: betänkande. Stockholm: Allmänna förlaget.

SOU 1993:57. Beskattning av fastigheter. Del 1. Schablonintäkt eller fastighetsskatt?: delbetänkande. Stockholm: Allmänna förlaget.

SOU 1994:57. Beskattning av fastigheter. Del 2. Principiella utgångspunkter för beskattning av fastigheter m.m.: slutbetänkande. Stockholm: Allmänna förlaget.

SOU 1999:59. Begränsad fastighetsskatt: delbetänkande. Stockholm: Fakta info direkt.

SOU 2000:10. Fastighetstaxering: precision, påverkansmöjligheter, individuella bedömningar: betänkande. Stockholm: Fritzes.

SOU 2000:34. Likformig och neutral fastighetsbeskattning. Stockholm: Fritzes.

SOU 2012:52. Bostadstaxering - avveckling eller förenkling. Stockholm: Fritzes.

Statistics Sweden (1914a-2012a). Statistical Yearbook of Sweden. Stockholm: Statistics Sweden.

Statistics Sweden (1920b). Kommunernas fattigvård och finanser. Andra avdelningen: Finanserna. Stockholm: Norstedts.

Statistics Sweden (1947c-1954c). Årsbok för Sveriges kommuner. Stockholm: Statistics Sweden.

Statistics Sweden (2010d). Finansmarknadsstatistik december 2010. Stockholm: Statistics Sweden and Sveriges Riksbank.

Öberg, Ann (2008). Incitamentseffekter av slopad fastighetsskatt. Rapport till Finanspolitiska rådet 2007/8. Stockholm: Finanspolitiska rådet. 